\begin{tabular}{lcl}
\hline & A N N A L E S \\
UNIVERSITATIS MARIAE CURIE-SKŁODOWSKA & LUBLIN - POLONIA \\
VOL. XLVIII, 2 & SECTIO H \\
\hline
\end{tabular}

Uniwersytet Marii Curie-Skłodowskiej w Lublinie, Katedra Gospodarki Światowej i Integracji Europejskiej

TOMASZ BIAŁOWĄS, MONIKA WOJTAS

\title{
The role of foreign value added in creating Poland's comparative advantage in world merchandise exports
}

\section{Rola zagranicznej wartości dodanej w tworzeniu przewagi komparatywnej Polski}

w światowym eksporcie towarowym

Keywords: Poland, exports, comparative advantage, foreign and domestic value added

Slowa kluczowe: Polska, eksport, przewaga komparatywna, zagraniczna i krajowa wartość dodana

\section{Introduction}

One of major trends in the world economy in the global era is international fragmentation of production, which means dividing previously integrated process into separate stages localized in various parts of the world. This allows to deepen specialization and achieve additional gains from trade especially in middle-income countries such as Poland.

There have been many theoretical papers on international fragmentation of production. The most significant are two that started two different approaches towards the issue. R. Jones and H. Kierzkowski [1990] view production process as fragments of production blocks that are located in different geographical locations linked with various services (administration, transportation, finance). Since diversification of labour productivity and factor cost is higher between countries rather than regions in a single country - fragmentation will be international. According to the standard approach, labour-intensive stages of production will be located in labour-abundant countries and capital-intensive activity - in capital-abundant countries. The second trend was initiated with a paper by D. Hummels, J. Ishii and K-M. Yi [2001]. They 
introduce a concept of vertical specialization with production tasks localized in various countries. This leads to the creation of global value added chain. A country accepts parts and intermediate goods that are processed and then passed on in a more advanced form to the next link of the chain for further processing. Both approaches complement each other, but the latter emphasizes the problem of value added in various countries.

Development of offshoring significantly alters countries' trade specialization and in consequence their revealed comparative advantage. However, the inadequacy of statistical data that relies mainly on the gross exports was a barrier to carrying out meaningful analysis. A turning point in research on fragmentation was construction of an alternative method of measuring trade flows based on value added. The theoretical basis for the method was developed in 1930s by the Nobel Prize winner W. Leontief [1936]. Existing papers using trade data in value-added terms revealed important discrepancies in comparative advantage, trade balance and geographical structure of exports and imports. R.C. Johnson and G. Nougera [2012] proved that real value of bilateral trade (depending on a country) was $3-50 \%$ lower than calculated using traditional measures.

The main goal of the paper is to evaluate the impact of international fragmentation on Poland's comparative advantage. The analysis will focus on:

1) level of internationalization of production and share of foreign value added in Poland's gross exports,

2) Poland's comparative advantage in international trade based on RCA indexes calculated according to the traditional (gross exports) as well as alternative method based on the concept of country's value added.

The calculations were carried out using data from OECD-WTO Trade in Value Added (TIVA) database and the time frame of the analysis, determined by the availability of data, was limited to 1995-2009.

\section{Research method}

One of the fundamental methods to evaluate the internationalization level of country's production and its engagement in international production networks is measuring the share of foreign value added in gross exports. Basic assumption in value-added to gross exports analysis is a possibility to assess national share of final product's value. We simplify by skipping taxes and subsidies. Then, final product value $\left(V^{P}\right)$ is a summation of all value-added (VA) in the process of production in subsequent countries. The formula is (1):

$$
V^{P}=\sum_{i} V A_{i}^{P}
$$

Net value added of country A (NVA) which constitutes its trade balance, is a difference between gross exports and imports as presented in formula (2). Gross exports is a summation of direct and indirect domestic value added (DVA) that country A is 
exporting and foreign value added (FVA) which consists of previously imported foreign parts and components used in the production process. Imports consists of 3 elements: 1) bilateral value added (BVA), 2) reimported value added (RVA) and multilateral value added (MVA). BVA is imports to country A of products which value was added in $100 \%$ in country B. RVA means those imported products which final value was added in country B as well as components coming from A. MVA is that part of imports from B that has value added from country C.

$$
N V A=(D V A+F V A)-(B V A+R V A+M V A)
$$

Standard measure used to assess comparative advantage in world exports is Balassa index [Balassa, 1965]. The Balassa index is defined as the ratio of country's share in world exports of a given industry divided by its share in overall world trade. More specifically, $B I_{j}^{A}$ is country $A$ 's Balassa index for industry $j$ defined as in formula (3). That is a ratio of share of industry $\mathrm{j}$ in country A exports $\left(s_{j}^{A}\right)$ and share of industry j in reference country R exports $\left(s_{j}^{R}\right)$. If $B I_{j}^{A}>1$, country $A$ is said to have a revealed comparative advantage (RCA) in industry $j$, since this industry is more important for country $A$ 's exports than for the exports of the reference countries.

$$
B I_{j}^{A}=\frac{s_{j}^{A}}{s_{j}^{R}}
$$

Poland's comparative advantage in international trade based on RCA indexes can be calculated in a traditional way using value of gross exports or in an alternative way - using domestic value added. In the first approach RCA value is determined by country's integration with international production networks and foreign value added. The second one allows to view in a more objective way the real comparative advantage in world exports.

\section{Share of foreign value added in Poland's gross exports}

Country's export potential is dependent not only on domestic enterprises export capability, but also on the activities of international corporations and nation's engagement in international production networks. Poland, in comparison to other economies of similar potential, is among most dependent on foreign components and intermediate goods. Furthermore, a significant increase in share of foreign value added in gross exports was noted in $1995-2008$ - it grew from $15.42 \%$ to $30.59 \%$. Due to global financial and economic crisis all the countries with the available data experienced a decrease in 2009. In Poland it fell to $27.89 \%$ (see Table 1). Share of foreign input into the gross exports is highly diversified among sectors of the economy. In 2009 
the following sectors were characterized by the highest share of foreign value added: transport equipment (38.93\%), electrical and optical equipment (34.07\%), basic metals and fabricated metal products (32.67\%), chemicals and non-metallic mineral products (32.50\%). The sectors with the lowest share of imported parts and components were low technology industries, dependent on labor and raw materials, such as: mining and quarrying (15.85\%), agriculture, hunting, forestry and fishing (16.64\%) (see Table 1).

Table 1. Share of foreign value added in gross exports in 1995-2009 by industry (in \%)

\begin{tabular}{|l|c|c|c|c|c|}
\hline \multicolumn{1}{|c|}{ Total } & 1995 & 2000 & 2005 & 2008 & 2009 \\
\hline Agriculture, hunting, forestry and fishing & 15.42 & 23.33 & 30.67 & 30.59 & 27.89 \\
\hline Mining and quarrying & 12.18 & 11.27 & 11.27 & 17.64 & 16.64 \\
\hline Food products, beverages and tobacco & 13.84 & 15.60 & 20.63 & 19.85 & 19.20 \\
\hline Textiles, textile products, leather and footwear & 14.78 & 29.48 & 32.76 & 31.13 & 29.81 \\
\hline Wood and paper & 14.24 & 24.15 & 27.71 & 24.13 & 23.12 \\
\hline Chemicals and non-metallic mineral products & 21.26 & 31.57 & 36.54 & 37.13 & 32.50 \\
\hline Basic metals and fabricated metal products & 19.92 & 28.17 & 34.48 & 37.92 & 32.67 \\
\hline Machinery and equipment & 17.25 & 24.14 & 30.80 & 31.63 & 29.38 \\
\hline Electrical and optical equipment & 14.65 & 33.97 & 42.69 & 35.87 & 34.07 \\
\hline Transport equipment & 19.72 & 32.83 & 45.82 & 40.51 & 38.93 \\
\hline Other manufacturing & 13.79 & 25.14 & 30.15 & 28.16 & 26.09 \\
\hline
\end{tabular}

Source: own compilation based on: OECD [2013].

Further analysis of foreign value added share in Poland's gross exports in various industries revealed the following trends. Share of foreign components and parts kept growing until 2005 in all sectors, except: 1) agriculture, hunting, forestry and fishing and 2) mining and quarrying. The highest growth occurred in industries with the most fragmented production processes. In 1995-2005 share of foreign value added in electrical and optical equipment increased by 28.04 percentage points, and in transport equipment - by 26.1 percentage points (see Table 1). In 2005-2008 share of imported parts in exports of the two aforementioned industries dropped. Similar tendencies characterized wood and paper, other manufacturing, textiles and footwear as well as food, beverages and tobacco. The remaining industries noted a steady growth until 2008.

Main sources of foreign components used to manufacture exported goods were countries of the European Union, mostly Germany. In 1995-2009 they accounted for $1 / 5$ of the total foreign value added in Polish exports. Apart from Germany other countries with significant shares were: Italy, France, the United Kingdom and the 
Netherlands. Outside the EU most components came from Russia, the United States, China, Japan and South Korea (see Table 2).

Table 2. Origin of foreign value added in Polish gross exports in 1995-2009 (in \%)

\begin{tabular}{|c|c|c|c|c|c|}
\hline & 1995 & 2000 & 2005 & 2008 & 2009 \\
\hline Total & 100.00 & 100.00 & 100.00 & 100.00 & 100.00 \\
\hline Domestic value added & 84.58 & 76.67 & 69.33 & 69.41 & 72.11 \\
\hline Foreign value added & 15.42 & 23.33 & 30.67 & 30.59 & 27.89 \\
\hline Germany & 3.11 & 4.41 & 6.25 & 5.51 & 5.21 \\
\hline Russia & 2.32 & 3.62 & 4.68 & 4.68 & 3.17 \\
\hline Italy & 1.04 & 1.71 & 2.13 & 2.03 & 2.03 \\
\hline United States & 1.33 & 1.64 & 1.44 & 1.59 & 1.71 \\
\hline France & 0.76 & 1.32 & 1.76 & 1.42 & 1.35 \\
\hline China & 0.10 & 0.25 & 0.66 & 1.30 & 1.30 \\
\hline United Kingdom & 0.93 & 1.26 & 1.26 & 1.06 & 0.97 \\
\hline Japan & 0.45 & 0.66 & 0.72 & 0.91 & 0.87 \\
\hline Netherlands & 0.46 & 0.64 & 0.81 & 0.78 & 0.78 \\
\hline Czech Republic & 0.32 & 0.52 & 0.81 & 0.79 & 0.75 \\
\hline South Korea & 0.09 & 0.46 & 0.50 & 0.67 & 0.73 \\
\hline Spain & 0.22 & 0.47 & 0.62 & 0.57 & 0.58 \\
\hline Belgium & 0.31 & 0.45 & 0.55 & 0.49 & 0.54 \\
\hline Austria & 0.42 & 0.48 & 0.55 & 0.55 & 0.52 \\
\hline Sweden & 0.40 & 0.63 & 0.70 & 0.57 & 0.50 \\
\hline Rest of the world & 3.16 & 4.81 & 7.23 & 7.67 & 6.88 \\
\hline
\end{tabular}

Source: own compilation based on: OECD [2013].

New version of the OECD database, updated in May 2013, increased its utility allowing to calculate input of each country of origin into foreign value added by industry. The data confirms that in 2009 main contributor of foreign components in all industries except chemicals and non-metallic mineral products was Germany (see Table 3). The new data also revealed high concentration of foreign value added origin. In transport equipment Germany, the United States and Italy accounted for $16.18 \%$ of foreign value added, and Germany's share was $9 \%$. In electrical and optical equipment share of Germany, the United States and China was $10.43 \%$, and in basic metals and fabricated metal products Germany, Russia and Italy contributed $12.65 \%$ of foreign value added. 
Table 3. Share of foreign value added in gross exports by industry and by source country in 2009 (in \%)

\begin{tabular}{|c|c|c|c|c|c|c|c|c|c|c|c|c|}
\hline & $\stackrel{\pi}{\stackrel{\pi}{0}}$ & 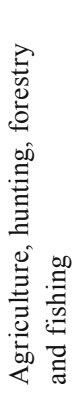 & 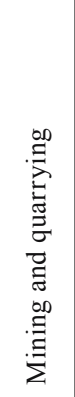 & 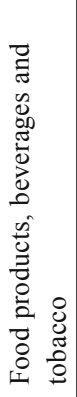 & 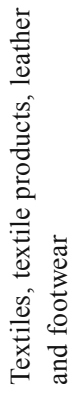 & 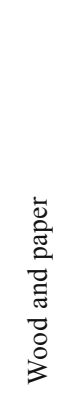 & 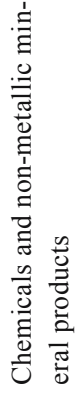 & 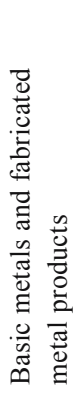 & 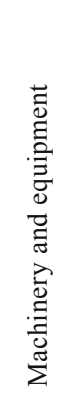 & 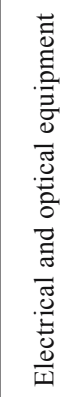 & 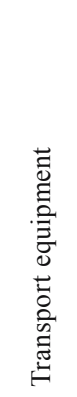 & 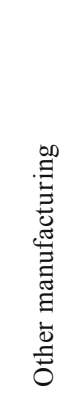 \\
\hline Total & 27.89 & 16.64 & 15.85 & 19.20 & 29.81 & 23.12 & 32.50 & 32.67 & 29.38 & 34.07 & 38.93 & 26.09 \\
\hline Germany & 5.21 & 2.71 & 2.77 & 3.35 & 5.24 & 5.07 & 5.01 & 6.32 & 5.79 & 5.30 & 9.00 & 5.33 \\
\hline Russia & 3.17 & 2.27 & 2.60 & 1.88 & 1.56 & 2.08 & 8.52 & 4.09 & 1.96 & 1.79 & 1.85 & 2.27 \\
\hline Italy & 2.03 & 0.88 & 1.12 & 0.95 & 3.39 & 1.16 & 1.52 & 2.24 & 2.25 & 1.76 & 4.31 & 1.79 \\
\hline United States & 1.71 & 0.96 & 0.94 & 1.14 & 1.40 & 1.45 & 1.74 & 1.52 & 1.74 & 2.14 & 2.87 & 1.35 \\
\hline France & 1.35 & 0.80 & 0.74 & 0.92 & 1.48 & 1.13 & 1.57 & 1.62 & 1.50 & 1.55 & 1.97 & 1.34 \\
\hline China & 1.30 & 0.55 & 0.65 & 0.65 & 2.16 & 0.70 & 0.92 & 1.34 & 1.66 & 2.99 & 1.71 & 1.20 \\
\hline United Kingdom & 0.97 & 0.62 & 0.51 & 0.65 & 1.10 & 0.81 & 1.12 & 0.96 & 1.02 & 1.30 & 1.29 & 0.85 \\
\hline Japan & 0.87 & 0.38 & 0.47 & 0.39 & 0.55 & 0.45 & 0.63 & 0.79 & 1.10 & 1.91 & 1.52 & 0.55 \\
\hline Netherlands & 0.78 & 0.64 & 0.38 & 0.83 & 0.85 & 0.68 & 0.85 & 0.77 & 0.85 & 1.35 & 0.87 & 0.68 \\
\hline Czech Republic & 0.75 & 0.48 & 0.40 & 0.62 & 0.68 & 0.65 & 0.78 & 1.06 & 0.79 & 0.71 & 1.15 & 0.81 \\
\hline South Korea & 0.73 & 0.27 & 0.37 & 0.29 & 0.51 & 0.32 & 0.46 & 0.74 & 1.01 & 2.07 & 1.07 & 0.45 \\
\hline Spain & 0.58 & 0.29 & 0.33 & 0.35 & 0.69 & 0.49 & 0.51 & 0.72 & 0.68 & 0.69 & 0.96 & 0.56 \\
\hline Belgium & 0.54 & 0.35 & 0.28 & 0.39 & 0.70 & 0.45 & 0.71 & 0.67 & 0.58 & 0.66 & 0.65 & 0.54 \\
\hline Austria & 0.52 & 0.25 & 0.29 & 0.33 & 0.46 & 0.70 & 0.48 & 0.73 & 0.60 & 0.50 & 0.79 & 0.58 \\
\hline Sweden & 0.50 & 0.24 & 0.27 & 0.34 & 0.64 & 0.80 & 0.46 & 0.68 & 0.56 & 0.55 & 0.65 & 0.56 \\
\hline Rest of the world & 6.88 & 4.95 & 3.73 & 6.12 & 8.40 & 6.18 & 7.22 & 8.42 & 7.29 & 8.80 & 8.27 & 7.23 \\
\hline
\end{tabular}

Source: own compilation based on: OECD [2013].

One of the industries highly engaged in international production networks was transport equipment. However, only $35.4 \%$ of foreign value added in gross exports in 2009 originated in the industry. Other components and intermediate goods were manufactured in basic metals $(8.14 \%)$, chemicals $(4.82 \%)$, mining and quarrying (3.12\%), electrical and optical equipment industry $(2.39 \%)$ [OECD, 2013]. Input of various services was much more significant, which is in accordance with theoreti- 
cal assumptions made by H. Kierzkowski and R.W. Jones [1990]. In 2009 services accounted for $40.94 \%$ of foreign value added in exports of transport equipment, in particular: wholesale and retail trade $-17.9 \%$, business services $-10.08 \%$, transport, storage and telecommunication $-5.29 \%$. In other industries share of services in foreign value added didn't surpass $40 \%$ and value added from the same industry amounted for a large share of foreign value added, especially in low technology and raw materials industries [OECD, 2013].

\section{Poland's comparative advantage in world merchandise trade}

In terms of traditional approach based on gross exports Poland had comparative advantage in exports of food products, beverages and tobacco, wood and paper, basic metals and fabricated metal products, other manufacturing and transport equipment (see Table 4). The largest gap characterized trade in electrical and optical equipment, machinery and equipment, chemicals and non-metallic mineral products, also after the year 2000 - textiles and footwear. Main trends in 1995-2009 were the following. In low and medium-low technology industries Poland's comparative advantage weakened. In contrast, there was a gain in comparative advantage in industries using advanced technologies. The highest growth of RCA indicator occurred in transport equipment (Balassa Index grew by 0.74), electrical and optical equipment $(0.33)$ and machinery and equipment $(0.30)$. These industries have the highest shares of foreign value added, over $30 \%$ of gross exports.

Table 4. Revealed comparative advantage indexes (RCA) of Poland calculated based on gross exports and domestic value added in 1995-2009

\begin{tabular}{|c|c|c|c|c|c|c|c|c|c|}
\hline & 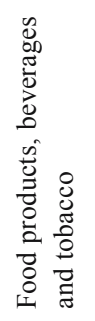 & 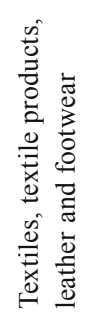 & 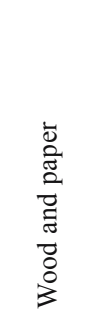 & 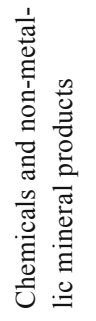 & 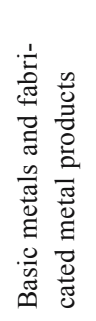 & 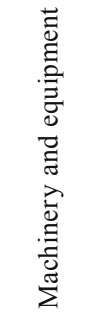 & 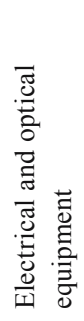 & 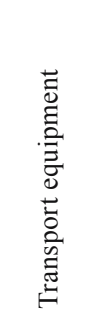 & 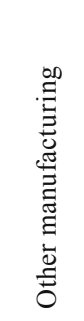 \\
\hline & \multicolumn{9}{|c|}{ Gross exports } \\
\hline 1995 & 1.7607 & 1.5541 & 1.3527 & 0.9966 & 1.8218 & 0.5080 & 0.2416 & 0.8069 & 2.1628 \\
\hline 2000 & 1.3807 & 1.4998 & 1.5833 & 0.9017 & 1.5471 & 0.6492 & 0.4123 & 1.1313 & 2.2300 \\
\hline 2005 & 1.5244 & 0.7708 & 1.4547 & 0.9216 & 1.2843 & 0.7713 & 0.5081 & 1.2334 & 1.9405 \\
\hline 2008 & 1.3083 & 0.8697 & 1.1273 & 0.8041 & 1.1016 & 0.8318 & 0.6263 & 1.5583 & 1.7043 \\
\hline 2009 & 1.4936 & 0.8597 & 1.2647 & 0.8212 & 1.0848 & 0.8114 & 0.5727 & 1.5469 & 1.6832 \\
\hline
\end{tabular}




\begin{tabular}{|c|c|c|c|c|c|c|c|c|c|}
\hline & 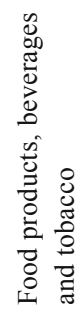 & 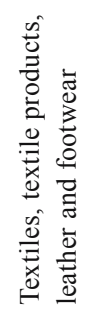 & 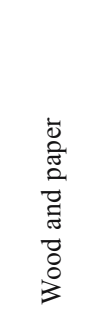 & 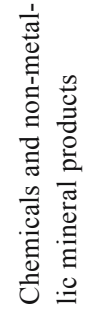 & 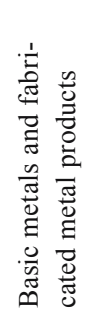 & 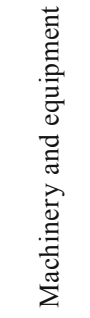 & 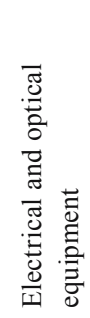 & 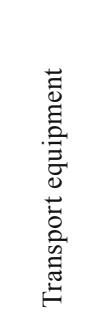 & 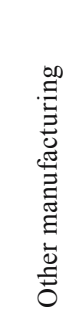 \\
\hline & \multicolumn{9}{|c|}{ Domestic value added } \\
\hline 1995 & 1.7406 & 1.6256 & 1.3220 & 0.9777 & 1.7805 & 0.4824 & 0.2583 & 0.7881 & 2.2199 \\
\hline 2000 & 1.4778 & 1.4168 & 1.5383 & 0.9126 & 1.5311 & 0.6425 & 0.3922 & 1.0994 & 2.2622 \\
\hline 2005 & 1.6392 & 0.7465 & 1.4449 & 0.9616 & 1.2836 & 0.7669 & 0.4911 & 1.0495 & 1.9842 \\
\hline 2008 & 1.3747 & 0.8309 & 1.1357 & 0.8359 & 1.0361 & 0.8061 & 0.6629 & 1.4222 & 1.7225 \\
\hline 2009 & 1.5311 & 0.8150 & 1.2392 & 0.8491 & 1.0528 & 0.7910 & 0.6026 & 1.3863 & 1.7142 \\
\hline
\end{tabular}

Source: own compilation based on: OECD [2013].

Using the alternative method of calculating Balassa indexes based on domestic value added significantly alters Poland's comparative advantage in world trade. RCA indexes in the following industries are considerably lower: transport equipment, machinery and equipment, basic metals and fabricated metal products, wood and paper, textiles and footwear. All of the above were characterized by a high share of foreign value added, which proves its important role in creating comparative advantage and export potential.

However, an assumption that high share of foreign value added in gross exports contributes to gaining comparative advantage in international trade is too far-fetched. The influence may be positive as well as negative. In case of transport equipment foreign value added caused an increase in comparative advantage. But in other cases the results were opposite. In electrical and optical equipment foreign value added amounted to $34 \%$ of gross exports in 2009 , but there was a high comparative gap. RCA indexes calculated in a traditional way were even slightly lower than those based on domestic value added.

\section{Conclusion}

Changes in the functioning of the world economy, cooperation and creation of international production networks requires a new approach to measuring trade and comparative advantage. It is necessary to assess share of the product's value that was added in the analyzed country to evaluate its position in international trade. The analysis carried out in this paper showed that foreign parts and components were an 
important element of Polish manufacturing exports and their role increased considerably in 1995-2009. Foreign value added was particularly important in high technology industries such as transport equipment or electrical and optical equipment while its role in low technology industries was minor. Large part of foreign value added was contributed by European Union countries and in particular Germany. The data also confirmed the theory that services sector is a significant source of foreign value added.

There is still a considerable gap in Polish exports competitiveness compared to the old European Union countries [Mucha-Leszko, Kąkol, 2009] so naturally there is a valid question whether foreign value added can be used to close this gap. However, the relation between comparative advantage and foreign value added was not proved to be straightforward. The Balassa indexes calculated using two methods were different, but the role of foreign input was not always positive. In some industries it allowed Poland to be more competitive (e.g. transport equipment) while in others it weakened the advantage/enlarged the gap.

\section{References}

1. Balassa B. 1965. Trade Liberalization and Revealed Comparative Advantage, "Manchester School of Economic and Social Studies", vol. 32.

2. Hummels D., Ishii J., Yi K-M. 2001. The nature and growth of vertical specialization in world trade, "Journal of International Economics", vol. 54, no. 1.

3. Johnson R.C., Noguera G. 2012. Accounting for intermediates: Production sharing and trade in value added, "Journal of International Economics", vol. 86.

4. Jones R.W., Kierzkowski H. 1990. The Role of Services in Production and International Trade: A Theoretical Framework, [in:] Jones R.W., Krueger A.O. (eds.), The Political Economy of International Trade: Essays in Honour of Robert A. Mundell, MIT Press, Cambridge.

5. Leontief W. 1936. Quantitative Input-Output Relations in the Economic System of the United States, "Review of Economics and Statistics", vol. 18, no. 3.

6. Mucha-Leszko B., Kąkol M. 2009. Will the financial economic crisis of 2008-2009 accelerate monetary integration in the EU?, "Eurolimes", vol. 8.

7. OECD, OECD-WTO Trade in Value Added (TIVA), http://stats.oecd.org/, (access: Sepember 2013)

\section{The role of foreign value added in creating Poland's comparative advantage in world merchandise exports}

The paper deals with changing approach to measuring trade an competitiveness due to the widely spread process of international fragmentation of production process which makes it much more difficult to assess origin of products in international trade. Therefore a method was developed to use foreign and domestic value added in order to evaluate country's role in world trade as well as its comparative advantage. Authors apply this methodology to Polish trade in goods in 1995-2009 and reveal that foreign components were an important part of its exports. Poland was highly dependent on foreign value added from European Union countries, especially Germany. Sectors with highest shares were: transport equipment, electrical and optical equipment, basic metals and fabricated metal products, chemicals and non-metallic mineral products. Foreign value added also affected Poland's comparative advantage - its 
impact on various industries was adverse. In some cases it improved RCA indexes while in others using domestic value added for the calculations resulted in a larger comparative advantage.

\section{Rola zagranicznej wartości dodanej w tworzeniu przewagi komparatywnej Polski w światowym eksporcie towarowym}

Internacjonalizacja produkcji sprawiła, że tradycyjne metody mierzenia udziału kraju w światowym eksporcie oraz przewagi konkurencyjnej w mniejszym stopniu odzwierciedlają rzeczywistość. W związku z tym zaczęły rozwijać się alternatywne metody mierzenia strumieni handlu zagranicznego - na podstawie wartości dodanej. Celem opracowania jest ocena wpływu międzynarodowej fragmentaryzacji produkcji na kształtowanie się pozycji konkurencyjnej Polski. Szczegółowa analiza obejmuje udział zagranicznej wartości dodanej w eksporcie brutto Polski oraz kształtowanie się przewagi konkurencyjnej na bazie indeksu Balassy, obliczonego na podstawie metody tradycyjnej (eksport brutto), jak również alternatywnej (krajowa wartość dodana). Zastosowanie nowego podejścia do analizowania polskiego eksportu ujawniło duży wzrost znaczenia zagranicznej wartości dodanej w badanym okresie. Źródłem jej pochodzenia były w znacznym stopniu kraje Unii Europejskiej, zwłaszcza Niemcy, a sektory, w przypadku których FVA miała największe znaczenie, charakteryzowały się dużym stopniem wykorzystania technologii. Należały do nich środki transportu oraz maszyny i urządzenia. Inne wartości przyjmowały także indeksy ujawnionej przewagi konkurencyjnej obliczone przy uwzględnieniu zagranicznej wartości dodanej. Założenie jednak, że wysoki udział zagranicznej wartości dodanej w eksporcie brutto powoduje poprawę pozycji komparatywnej kraju w handlu międzynarodowym, jest zbyt daleko idącym uproszczeniem. Może mieć ona pozytywny wpływ, ale w niektórych sektorach okazał się on bardzo niewielki albo nawet wartości wskaźników były nieznacznie wyższe przy uwzględnieniu jedynie krajowej wartości dodanej. 